trast color is measured to a certain extent in terms of the saturation of the inducing color, especially where the reacting field is completely surrounded as in Meyer's experiment. Hence, when the inducing color is only slightly saturated the contrast effect looks to us stronger, though based on a weaker physiological process; when the inducing color is saturated, the contrast effect is underestimated by comparison. This conclusion is borne out by the fact that in the quantitative experiments, when the inducing color lay only on the outside of the reacting surface and a comparison disk was used, the contrast effect increased steadily with the saturation.

VASSar Col,LEgE.

M. F. WASHBURN.

\title{
DISCUSSION.
}

\section{REACTION-TIME AND VARIABILITY: A CRITICISM.}

In the May number of the Psychological Raview William $R$. Wright published a paper on 'The Relation between the Vaso-Motor Waves and Reaction Times,' in which he presented reaction-time results which indicate certain important relations between the vasomotor wave and the time of reaction. The author gives in his report of experiments only the averages of his reaction-time series: in no case is variability mentioned. In view of the obvious importance of the variableness of reaction-time in our interpretation of the signifcance of such results as are offered in this paper, it is surprising that the author should not have given, at least, the mean variability of each series.

I have recently called attention to the necessity for the determination of variability and probable errors in all reaction-time work, ${ }^{1}$ and I refer to the matter again in this connection only because reports are continually appearing whose value is greatly diminished by the neglect of this matter. It is needless to say that a difference in reaction-times, which under certain conditions may be significant, under slightly different conditions may justify no conclusion beyond that of variability. In other words, unless our results show differences which exceed the variability or probable error of the average reaction-times we are not justified in basing conclusions upon such differences. It is true that the results of the paper in question are so constant in their indication of a certain relationship that the author may have thought

' Yerkes, Robert M.; 'Variability of Reaction-Time,' PsychoLOGICAI BoLlarre, Vol. I., pp., 137-r46, 1904 . 
it useless to bother with other statistical data than the average reactiontimes; but even granting this, there can be no doubt that the meaning of the results and their value for future investigators would have been made clearer by the determination of some statistical measure of their variableness.

HARVARD UNTVERSTTY.

ROBERT M. YERKES.

\section{CORRECTION.}

The review of Professor Royce's article on pp. 320-324 of the August Buldztin was written by Miss Angie L. Kellogg, of Vassar College, and should have been so signed. We regret the error.

\section{BOOKS RECEIVED FROM AUGUST 7 TO SEPTEMBER 7 .}

The Decline of Land-owning Farmers in England. H\#NRY Charles Taylor, Ph.D. Bull. of the Univ. of Wisconsin. Madison, Wis., rg04. Pp. 66.

Condorcet, Guide de la Revolution franfaise. Franck Alengry. Paris, Giard et Brière, I904. Pp. 889.

Interrogative Thought and the Means of its Expression. EDward T. OwEr, Ph.D. From Trans. of the Wisc. Acad. of Sciences, Arts and Letters, Vol. XIV.

Kants Revolutionsprinzip (Kopernikanisches Prinzip). ERNst Marcus. Herford, W. Menckhoff, I902. Pp. xii +181 .

A Treatise on Cosmology. Herbert Nichols. Vol. I., Introduction. Cambridge, Mass., The Author, 1904. Pp. 454.

Wissenschaft und Weltanschauung. MAX WrRworN. Leipzig, Barth, 1904. Pp. 48.

Einführung in die Psychologie. Almx. PFänder. Leipzig, Barth, rgo4. Pp. vii + 423. M. 6.

Evolution of Theology in the Greek Philosophers. Ed. CAIRd. 2 vols. Glasgow, Maclehose, 1904. Vol. i, pp. xvii +372 . Vol. ii, $\mathbf{x i}+377$.

Unterrichtspraxis für das Gesammtgebiet des ersten Schuljahrs. L. F. Gobelbecker. Wiesbaden, Nemnich, 1904. Pp. ix + 459 . 